\title{
Assessing Diet Quality of Indigenous Food Systems in Three Geographically Distinct Solomon Islands Sites (Melanesia, Pacific Islands)
}

\author{
Chris Vogliano ${ }^{1, *(\mathbb{D}}$, Jessica E. Raneri ${ }^{2} \mathbb{D}$, Josephine Maelaua ${ }^{3}$, Jane Coad ${ }^{4} \mathbb{D}$, Carol Wham ${ }^{5}$ and \\ Barbara Burlingame ${ }^{1}(\mathbb{D})$
}

1 School of Health Sciences, Massey University, Wellington Campus, Wellington 6021, New Zealand; barbara.burlingame@gmail.com

2 Department of Food Technology, Safety and Health, Ghent University, 9000 Ghent, Belgium; jessicaraneri@gmail.com

3 Faculty of Nursing, Medicine and Health Sciences, Solomon Islands National University (SINU), Honiara P.O. Box R113, Solomon Islands; josephine.maelaua@sinu.edu.sb

4 School of Food and Advanced Technology, Massey University, Manawatū Campus, Manawatū 4442, New Zealand; j.coad@massey.ac.nz

5 School of Sport, Exercise and Nutrition, Massey University, Albany Campus, Auckland 0632, New Zealand; c.wham@massey.ac.nz

* Correspondence: chrisvogliano@gmail.com

Citation: Vogliano, C.; Raneri, J.E.;

Maelaua, J.; Coad, J.; Wham, C.;

Burlingame, B. Assessing Diet

Quality of Indigenous Food Systems

in Three Geographically Distinct

Solomon Islands Sites (Melanesia,

Pacific Islands). Nutrients 2021, 13, 30.

https://doi.org/10.3390/nu13010030

Received: 16 November 2020

Accepted: 16 December 2020

Published: 23 December 2020

Publisher's Note: MDPI stays neutral with regard to jurisdictional claims in published maps and institutional affiliations.

Copyright: () 2020 by the authors. Licensee MDPI, Basel, Switzerland. This article is an open access article distributed under the terms and conditions of the Creative Commons Attribution (CC BY) license (https: / / creativecommons.org / licenses/by/4.0/).

\begin{abstract}
Indigenous Solomon Islanders, like many living in Pacific Small Island Developing States (PSIDS), are currently experiencing the global syndemic - the combined threat of obesity, undernutrition, and climate change. This mixed-method study aimed to assess nutrition transitions and diet quality by comparing three geographically unique rural and urban indigenous Solomon Islands populations. Participants in rural areas sourced more energy from wild and cultivated foods; consumed a wider diversity of foods; were more likely to meet WHO recommendations of $>400 \mathrm{~g}$ of non-starchy fruits and vegetables daily; were more physically active; and had significantly lower body fat, waist circumference, and body mass index (BMI) when compared to urban populations. Urban populations were found to have a reduced ability to self-cultivate agri-food products or collect wild foods, and therefore consumed more ultra-processed foods (classified as NOVA 4) and takeout foods, and overall had less diverse diets compared to rural populations. Clear opportunities to leverage traditional knowledge and improve the cultivation and consumption of underutilized species can assist in building more sustainable and resilient food systems while ensuring that indigenous knowledge and cultural preferences are respected.
\end{abstract}

Keywords: indigenous peoples; food systems; sustainable diets; wild foods; food security; nutrition; SDG 2; Pacific Islands; biodiversity

\section{Introduction}

Indigenous Solomon Islanders, like many living in Pacific Small Island Developing States (PSIDS), are currently experiencing the global syndemic, which is the combined threat of obesity, undernutrition, and climate change [1]. Climate change is predicted to challenge accumulated traditional food knowledge through changing landscapes and weather patterns and rising sea levels, with the highest sea rises predicted to occur near the equator [2]. The Solomon Islands (Melanesia) are considered to be a biodiversity hotspot, containing vast genetic diversity and traditional knowledge, which are valuable assets towards ensuring resilient and sustainable food systems in the future [3-5]. However country-level import data suggest that ultra-processed foods such as carbonated soft drinks, baked foods, processed meats, noodles, and sweet biscuits make up the majority of imports in transitioning PSIDS [6]. Additionally, mounting evidence suggests that sharp rises in 
tropical log exports are degrading local fisheries [7], being linked to decreased ecological resilience and a rise in wealth inequality among Solomon Islanders [8]. Therefore, this study aimed to assess diet quality and food system transitions across three geographically unique Solomon Islands populations.

According to the Committee on World Food Security, food security and nutrition policy are best approached within a sustainable food system framework underpinned by the right to food [9]. A sustainable food system has been defined as "a food system that delivers food security and nutrition for all in such a way that the economic, social and environmental bases to generate food security and nutrition for future generations are not compromised" [10]. The majority of Solomon Islanders live in rural communities and have traditionally relied on subsistence agriculture and fish as their primary source of nutrition [11]. However, knowledge of recent nutrition transitions and associated nutrient contributions of indigenous food systems is limited, particularly when comparing rural populations with rapidly urbanizing populations.

One recent dietary diversity study conducted in the peri-urban population of Malaita [12] found that diet diversity is higher in rural areas compared with peri-urban populations, but it is unknown as to how these findings relate to the urban capital of Honiara, where most urban Solomon Islanders reside. Another recent study found poor dietary diversity among women and young children in rural Solomon Island populations (Western Province and Malaita), with diets dominated by grains, white roots, tubers, and plantains [13]. To understand the relationship between traditional knowledge and barriers to healthy diets, it is critically important to assess diet quality; diversity; sourcing patterns; and the knowledge, attitudes, and practices of those living in geographically unique areas in Solomon Islands [12].

This study aimed to assess nutrition transitions by comparing quantitative anthropometric measurements, diet quality measurements, and food sourcing patterns among three geographically unique rural and urban indigenous Solomon Island populations. Additionally, qualitative key informant interviews were used to contextualize the quantitative data by identifying emerging concerns towards healthy and sustainable foods systems. Quantitative data were collected through the administration of a comprehensive nutrition survey and participatory quantitative interviews with village elders and other key informants

\section{Methods}

\subsection{Study Sites}

This research took place in 3 geographically distinct sites across the Solomon Islands, including representation from both rural and urban populations. Snowball sampling was used at each of the 3 sites to ensure randomized sampling. The 2 rural study sites are distinguished by their access to the ocean. The first study site and subsequent 2 study sites were assessed 1 year apart during the same season. The first study site was Baniata village (visited August 2018), a rural coastal village comprised of $\approx 80$ households ( $\approx 645$ people) and surrounded by native bush and mountains (Figure 1a). Baniata is located on Rendova Island, Western Province, and is accessible only by boat from the neighboring region of Munda. The second study site (visited in 2019) comprised a collection of 8 smaller rural inland villages in Eastern Central Guadalcanal (Figure 1b; Besu, Chokare, Komunibia, Sili, Kukudu, Masa, Kodali, and Tughuru). Accessing these inland villages required a 3-h drive on dirt roads, followed by a 2-h hike through native bush. Travelling between villages required a local guide who led our team through the jungle and across rivers to reach individual households. Each village contained 5-10 households, with a total of $\approx 430$ individuals and 50 households across all 8 villages. These rural inland villages were geographically and culturally similar enough to group them into one population. Rural coastal and inland sites had no cellular service, internet, or electricity (with the exception of a few small solar panels). The final study site was an urban community (visited in September 2019) located in the neighboring villages of Jericho 1 and Jericho 2 with $\approx 5000$ people (Figure $1 \mathrm{~b}$ ). These urban populations serve as proxies for the larger urban population living in Honiara, the largest city and capital of Solomon Islands, with 
a total population of $\approx 84,520$. Over $80 \%$ of Solomon Islanders live outside of Honiara in rural areas.

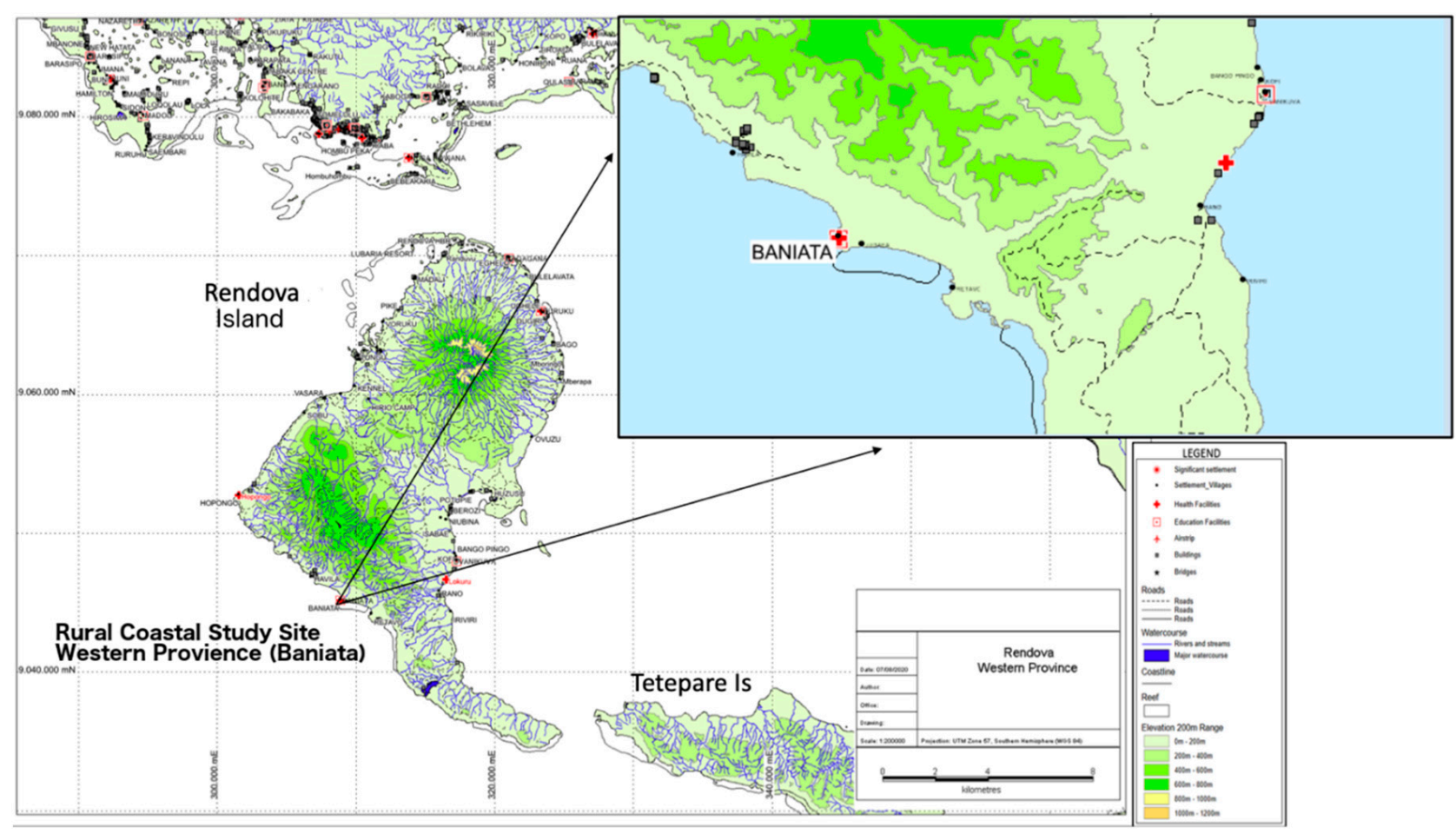

(a)

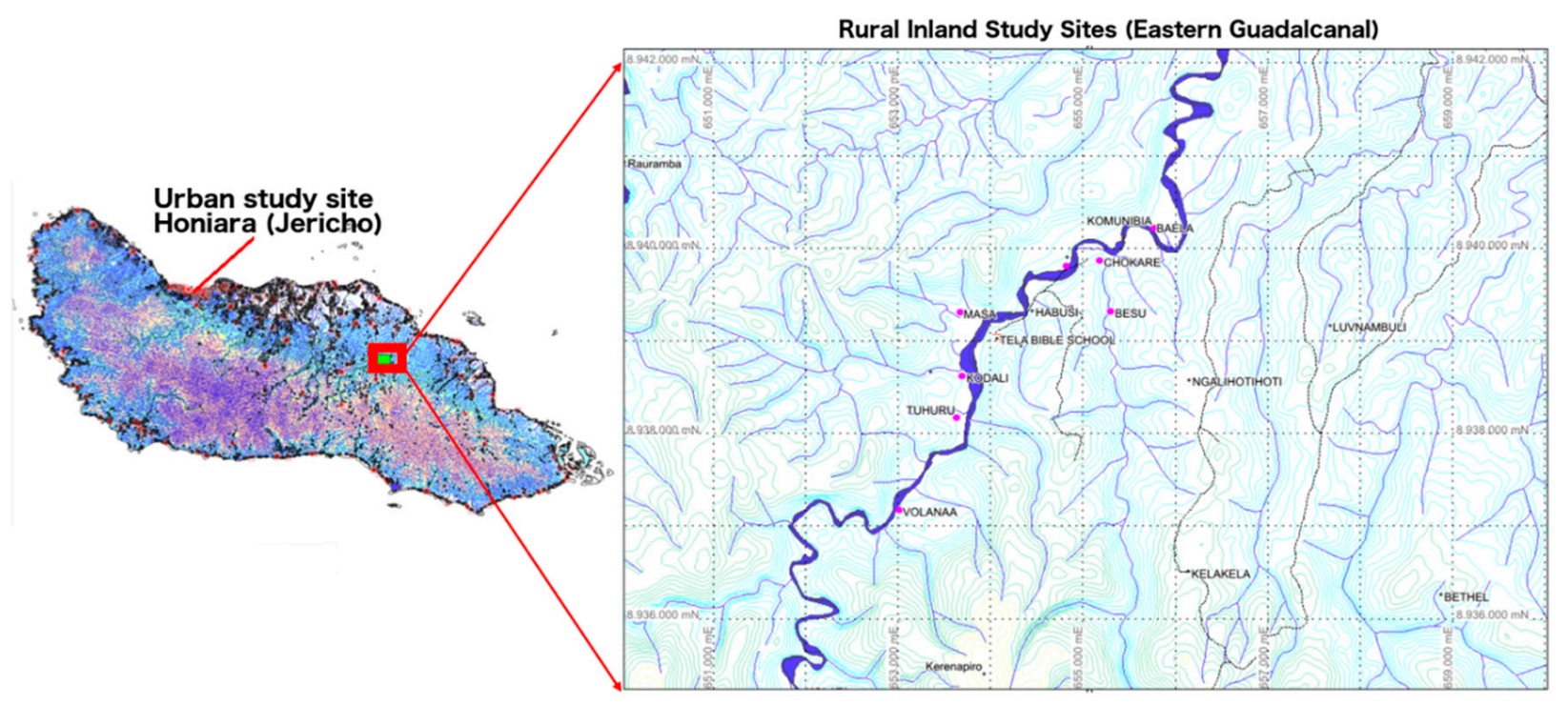

(b)

Figure 1. (a) Rural coastal study site, Baniata Village, Western Province. (b) Urban study site (Honiara, Jericho 1 and 2 ), and rural inland study sites (Eastern Guadalcanal). (a,b) are provided by Carlos Maelaua, a consulting geologist in the Solomon Islands. 


\subsection{Study Design}

We used an observational mixed-method cross-sectional study design. Quantitative surveys were administered to the woman in each participating household who was primarily responsible for household food preparation and agri-food cultivation. Dietary intakes were assessed using the repeat $24 \mathrm{~h}$ multiple-pass recall (MPR) method; questionnaires were used to assess knowledge, attitudes and practices (KAP), and food insecurity; and anthropometric measurements were undertaken. Qualitative key informant interviews were held in each village with village elders, and sometimes additional community members, in order to build understanding around current food systems and forecasted food system changes.

The Solomon Islands is home to over 75 distinct languages. Research tools were translated and conducted in the most commonly used language, called pidgin, in order to accommodate language diversity. All survey materials and qualitative key informant questions were pretested in consultation with the nutrition and dietetics professionals from Solomon Island National University for cultural appropriateness, comprehension, and respect for indigenous perspectives and values. Prior to data collection at each study site, dietitian enumerators consulted with village chiefs to ensure sensitive topics were respected and activities that may be considered taboo were avoided.

The first phase of research took place in August 2018 in the rural coastal village of Baniata. The second phase, which included the inland rural sites in Eastern Central Guadalcanal and the urban site in Honiara, took place in September 2019. The second phase study design was modified slightly on the basis of adaptations and feedback from the first phase.

Eight local dietitians/nutritionists from the Solomon Islands National University led the quantitative nutrition survey assessments and qualitative focus group discussions at each study site, and also attended a multiday training to ensure comprehension of the research methodologies. Ethical approval was obtained from the Massey University Human Ethics Committee (\#4000020954), as was research clearance from the Solomon Islands Ministry of Education and Human Resources and Development (MEHRD \#0668216) and the Solomon Islands National Health and Research Committee prior to commencing this study. Village chiefs were notified, and they granted consent before study commencement.

\subsection{Quantitative Nutrition Surveys}

Households within each population were randomly selected using a snowball sampling technique. Nutritionists collected quantitative data from women (aged 15-49) who were primarily responsible for cultivating and preparing household foods $(n=94)$. Women were excluded if they were pregnant or lactating, due to increased energy and nutrient requirements [14]. Nutritionists walked to each selected household and conducted anthropometric measurements, $24 \mathrm{~h}$ multiple-pass food recalls (MPRs), and a nutrition survey in each participant's kitchen (when appropriate).

\subsection{Anthropometry}

Anthropometric measurements included height, weight, and body fat percentage for participants in all of the villages across the 3 study sites. Participants who lived in inland and urban populations were also measured for waist (within $0.1 \mathrm{~cm}$ ) and calf circumference (within $0.1 \mathrm{~cm}$ ). Height (within $0.1 \mathrm{~cm}$ ) was assessed using a tape measure, and each nutritionist was trained accordingly with best practices, including the removal of excess clothing and having the individual stand on a flat surface without shoes [15]. Weight $(0.1 \mathrm{~kg})$ was measured using a portable digital weight scale (GreaterGoods Digital Body Fat Scale, Model 0391). Body fat percentages $(0.1 \%)$ were assessed using a comprehensive bioelectric impedance body composition analyzer (InBody S10). Body mass index (BMI) was calculated from the participants' height and weight $\left(B M I=\mathrm{kg} / \mathrm{m}^{2}\right)$. 


\subsection{H Multiple Pass Recalls}

Quantitative $24 \mathrm{~h}$ multiple-pass recalls ( $24 \mathrm{~h}$ MPR) were conducted across 2 nonconsecutive days to represent realistic dietary intakes of participating women [16]. Dietary recalls were adapted to capture both species- and variety-level biodiversity of each consumed food. In addition to types and quantities of foods consumed, cooking methods and brands were also recorded. The sourcing of each ingredient was also captured, and included selfcultivated foods, wild foods, store-bought foods, market purchases, and takeaway foods. If the participant had leftover food or drinks from the previous day's meal, nutritionists directly measured the amount consumed as determined by the participant $(\approx 35 \%$ of meals). Portion sizes were estimated by the participant and weighed using digital kitchen scales (Etekcity model EK6015) or measured using graduated cylinders $(500 \mathrm{~mL}$ and $1000 \mathrm{~mL}$ ). If the food or drink were not available for direct measurement, then participants estimated quantities of food or drink using water, modelling clay, or strips of paper in the participant's original dishware. Displacement techniques were utilized to determine portion sizes if clay or paper were used to determine portion size. After, food quantities were determined by converting the quantities or densities of the clay/paper by using food density conversion factor estimates from the FAO International Network of Food Data Systems (INFOODS) Density Database [17]. The interview also probed for ingestion of dietary supplements and alcohol.

Food and ingredient source categories included self-cultivated or produced, wild collected, wet market, convenience store, or takeaway meals. Self-cultivated foods are foods intentionally produced by the household for consumption. Wild-collected foods included foods not intentionally cultivated but collected from forests, rivers, or the ocean. Wet market foods are locally sourced from a produce or meat market. Convenience store foods are those foods purchased within a brick-and-mortar shop or a canteen. Takeaway meals are ready-to-eat foods purchased from a street vendor or restaurant.

Nutritional composition data and food groups were sourced from the Pacific Island Food Composition Database (Version 2) [18], Australia and New Zealand food composition databases, and the FAO/INFOODS databases [17]. Food Works (Xyris Version Version 10.0.1) was used to calculate nutrient losses and retentions from food preparation styles (i.e., boiling, drying, etc.). Food varieties that could not be identified in food composition databases were substituted for closely comparable foods. Usual nutrient intakes were calculated from 2 nonconsecutive day $24 \mathrm{~h}$ MPRs using the multiple source method (MSM) [19]. Diet consumption data were categorized into the food groups used in the Minimum Dietary Diversity for Women (MDD-W). The level of food processing was classified using NOVA 1-4 categories, with NOVA 4 capturing exclusively ultra-processed foods [20].

The Minimum Dietary Diversity Score for Women (MDD-W) is a proxy for the probability of micronutrient adequacy for women aged 15-49 [21]. Food groups were extracted from consumption data in $24 \mathrm{~h}$ MPRs and served as a binary indicator of dietary diversity. Diets that contain five or more food groups (out of a possible 10) have a higher likelihood of achieving micronutrient adequacy [21]. Dietary species richness (DSR) was used to assess agrobiodiversity, and was calculated by counting the unique number of species consumed during each $24 \mathrm{~h}$ MPRs [22].

\subsection{FAO's Food Insecurity Experience Scale (FIES)}

The Household Food Insecurity Experience Scale (FIES) of the Food and Agriculture Organization of the United Nations [23] is an 8-item binary question scale designed to estimate annual household levels of food insecurity. Scores range from 1 to 8 , with an average score from 1 to 3 classified as low annual household food insecurity, 4 to 6 as moderate, and 7 to 8 as severe [24]. The FIES is an indicator for SDG 2 (2.1.2).

\subsection{International Physical Activity Questionnaire (IPAQ-SF)}

The International Physical Activity Questionnaire Short Form (IPAQ-SF) is a 7-item survey designed to quantify weekly physical activity and related intensities for each 
participant. The IPAQ-SF was adapted to accommodate common activities throughout the Solomon Islands. Three categories of physical activity were used for comparison: low activity, moderate activity, and high activity. Results were converted into MET minutes (metabolic equivalent of task). IPAQ-SF was calculated and analyzed using the IPAQ scoring protocol outlined by the IPAQ Group [25], classified as low, moderate, or high activity. IPAQ-SF was added to the surveys for the second phase of the study in rural inland and urban sites but were not included in the rural coastal site.

\subsection{Knowledge, Attitudes, and Practices (KAP)}

Following FAO guidelines, we asked a series of questions to assess the participants' knowledge, attitudes, and practices (KAP) regarding nutrition, agricultural practices, and food waste [26]. The KAP questions were designed to identify specific barriers to accessing and preparing healthy foods. All KAP questions were pretested with local dietitians to ensure comprehension and cultural sensitivities. Data were analyzed to identify how women's knowledge and attitudes influenced practices related to household food preparation. Post-harvest garden and household food waste was estimated by the primary cook of household, with primary foods and reasons for loss recorded.

\subsection{Quantitative Data Analysis}

Nutrition surveys including $24 \mathrm{~h}$ MPRs, KAP, anthropometric measurements, and descriptive data were analyzed using IBM SPSS (Version 25), Tableau (Version 2020.1), RStudio (1.2.5001), and Xyris FoodWorks (Version 10.0.1).

Percentage of participants consuming less than the estimated average requirement (EAR) was used to estimate the prevalence of inadequate nutrient intakes. EAR is defined as the average daily nutrient intake level that is estimated to meet the requirements of $50 \%$ of the healthy individuals in a particular life stage and gender group [27]. The population prevalence of inadequate intakes was computed using the EAR cut point method for each unique study site [28]. The EAR cut point method was computed by calculating the proportion of individuals with usual intakes below the EAR for calcium, vitamin $B_{12}$, folate, selenium, potassium, vitamin $\mathrm{A}_{\mathrm{eq}}$, thiamine, and zinc. The full probability approach was used to determine average probability of inadequacy for iron. This approach is necessary to adjust for absorption limits and iron losses among menstruating women [(Observed Intake $\times$ Upper limit) -0.87 (assumed basal loss of iron)] [29].

The World Health Organization and the FAO recommend a minimum of $400 \mathrm{~g}$ of non-starchy fruit and vegetables (NSFV) per day to prevent chronic diseases such as heart disease, cancer, diabetes, and obesity, as well as to prevent and alleviate several micronutrient deficiencies, especially in less developed countries [30]. NSFV intakes were extracted from $24 \mathrm{~h}$ MPRs and compared to the WHO/FAO recommendation of $400 \mathrm{~g} /$ day.

Linear regression models were used to demonstrate the relationship between body fat percentage and the average number of species consumed (DSR), knowledge of healthy diets, and consumption of dark leafy vegetables, with $p \leq 0.05$ regarded as significant.

\subsection{Estimation of Misreporting of Dietary Intake Data}

Misreporting of dietary intake data was controlled for using Goldberg cutoff points. Cutoff points were calculated by comparing energy intakes (EI) with estimated basal metabolic rate $\left(\mathrm{BMR}_{\mathrm{est}}\right)$ using the Harris-Benedict equation $[\mathrm{BMR}=(10 \times$ Weight $)+(6.25$ $\times$ Height $)-(5 \times$ Age $)-161$ ] [31]. Underreporting was defined as EI: $\mathrm{BMR}_{\text {est }}<1.15$, and overreporting as $>1.96$ [32].

\subsection{Village Comparisons}

A one-way ANOVA was used to determine intra-village differences in anthropometric, lifestyle, and diet quality data. Normality checks and Levene's test were conducted and the assumptions met. Post hoc comparisons using the Tukey test were carried out. 


\subsection{Qualitative Analysis}

Key informant interview questions were structured on the basis of previously conducted surveys in the Solomon Islands aimed at characterizing the sustainability of indigenous food systems. Data were summarized to contextualize quantitative findings using the qualitative software NVIVO 12 (Version 12.6).

\section{Results}

\subsection{Food System Comparisons}

Comparisons between three geographically distinct indigenous Solomon Island food systems are provided for rural coastal, rural inland, and urban populations in Table 1. Clear distinctions were found between rural and urban populations, including population size, accessibility, proximity to markets, agri-food production, and wild food collection.

Table 1. Characteristics and food system descriptors for three geographically unique indigenous Solomon Island populations.

\begin{tabular}{|c|c|c|c|}
\hline Descriptor & Rural Coastal & Rural Inland & Urban \\
\hline Sample size & Households $(n=30)$ & Households $(n=32)$ & Households $(n=33)$ \\
\hline Village name (s) & Baniata & $\begin{array}{l}\text { Multiple villages (Besu, } \\
\text { Chokare, Komunibia, Sili, } \\
\text { Kukudu, Masa, Kodali, } \\
\text { Tughuru) }\end{array}$ & Jericho 1 and Jericho 2 \\
\hline Location & $\begin{array}{l}\text { Coastal village on Rendova } \\
\text { Island in the Western Province }\end{array}$ & $\begin{array}{c}\text { Eastern rural inland villages, } \\
\text { Guadalcanal }\end{array}$ & $\begin{array}{l}\text { Honiara (capital city), } \\
\text { Guadalcanal }\end{array}$ \\
\hline Population & $\begin{array}{l}\approx 645 \text { villagers and } 80 \\
\text { households }\end{array}$ & $\begin{array}{l}\approx 430 \text { villagers and } 50 \\
\text { households }\end{array}$ & $>84,500$ (total population) \\
\hline Season & $\begin{array}{l}\text { Lean season (July/August } \\
\text { 2018) }\end{array}$ & $\begin{array}{c}\text { Rainy season } \\
\text { (August/September 2019) }\end{array}$ & $\begin{array}{c}\text { Rainy season } \\
\text { (August/September 2019) }\end{array}$ \\
\hline Food insecurity (FIES) & $\begin{array}{l}\text { FIES Composite: } 4.1 \\
\text { Moderate food insecurity }\end{array}$ & $\begin{array}{l}\text { FIES Composite: } 2.5 \\
\text { Low food insecurity }\end{array}$ & $\begin{array}{l}\text { FIES Composite: } 2.2 \\
\text { Low food insecurity }\end{array}$ \\
\hline $\begin{array}{l}\text { Household monthly income } \\
\text { (average) }\end{array}$ & $\begin{array}{c}\text { SBD } 1043 \text { (USD 125) } \\
\text { [SD SBD } 416 \text { (USD 53)] }\end{array}$ & $\begin{array}{c}\text { SBD } 965 \text { (USD 115) } \\
\text { [SD SBD } 569 \text { (USD 68)] }\end{array}$ & $\begin{array}{c}\text { SBD } 1115 \text { (USD 133) } \\
\text { [SD SBD } 719 \text { (USD 86)] }\end{array}$ \\
\hline Household size (average) & $\begin{array}{l}6.5 \text { people per household } \\
\text { (SBD } 160 \mathrm{pp} / \mathrm{month})\end{array}$ & $\begin{array}{l}5.1 \text { people per household } \\
\text { (SBD } 193 \mathrm{pp} / \mathrm{month})\end{array}$ & $\begin{array}{l}6.9 \text { people per household } \\
\text { (SBD } 161 \mathrm{pp} / \text { month) }\end{array}$ \\
\hline Accessibility & $\begin{array}{l}\text { Village access requires a } \\
\text { 90-min commute from the } \\
\text { regional capital of Munda on } \\
\text { a wooden petrol-powered } \\
\text { fishing boat. }\end{array}$ & $\begin{array}{l}\text { Village access requires a 3-h } \\
\text { drive on dirt roads and across } \\
\text { rivers from the capital city of } \\
\text { Honiara, followed by a 2-h } \\
\text { trek to reach inland river } \\
\text { villages. }\end{array}$ & $\begin{array}{c}\text { Villages are centrally located } \\
\text { within the urban capital of } \\
\text { Honiara. }\end{array}$ \\
\hline Proximity to external markets & $\begin{array}{l}\text { The closest wet market was } \\
\text { located in Noro, which } \\
\text { requires boat access. Baniata } \\
\text { had } 2 \text { boats, which limits the } \\
\text { number of villagers who are } \\
\text { able to sell their agri-food } \\
\text { products each day. }\end{array}$ & $\begin{array}{l}\text { The closest wet market is in } \\
\text { Honiara (above) and takes a } \\
\text { considerable amount of time } \\
\text { to access. }\end{array}$ & $\begin{array}{l}\text { Neighborhood markets } \\
\text { external to Jericho exist, but } \\
\text { the Honiara central market is } \\
\text { the closest. Walking would } \\
\text { take } 1.5 \mathrm{~h} \text {, and a bus would } \\
\text { take } 30 \text { min (during business } \\
\text { hours). }\end{array}$ \\
\hline Internal markets or canteens & $\begin{array}{l}\text { An internal canteen exists } \\
\text { with a limited selection of } \\
\text { basics such as noodles, flour, } \\
\text { oil, rice, biscuits, candies, and } \\
\text { tobacco products. }\end{array}$ & $\begin{array}{l}\text { An internal canteen exists } \\
\text { with a limited selection of } \\
\text { basics such as noodles, flour, } \\
\text { oil, rice, biscuits, candies, and } \\
\text { tobacco products. }\end{array}$ & $\begin{array}{c}\text { No internal market exists, but } \\
\text { street foods, select produce, } \\
\text { and basics are available for } \\
\text { sale directly outside of the } \\
\text { village. }\end{array}$ \\
\hline
\end{tabular}


Table 1. Cont.

\begin{tabular}{|c|c|c|c|}
\hline Descriptor & Rural Coastal & Rural Inland & Urban \\
\hline $\begin{array}{l}\text { Agri-food cultivation and } \\
\text { production }\end{array}$ & $\begin{array}{l}\text { All women participated in } \\
\text { agri-food cultivation and } \\
\text { production and market sales. }\end{array}$ & $\begin{array}{l}\text { All women participated in } \\
\text { agri-food cultivation and } \\
\text { production and market sales. }\end{array}$ & $\begin{array}{l}\text { Women were less involved } \\
\text { with agri-food production, } \\
\text { cultivation, and sales and had } \\
\text { a wider variety of } \\
\text { responsibilities, including the } \\
\text { formal sector or as a caretaker. }\end{array}$ \\
\hline Wild food access & $\begin{array}{l}\text { Ocean and bush were } \\
\text { accessible to all villagers, and } \\
\text { wild foods were collected to } \\
\text { supplement diets. }\end{array}$ & $\begin{array}{l}\text { River and bush access were } \\
\text { accessible to all villagers, and } \\
\text { wild foods were collected to } \\
\text { supplement diets. }\end{array}$ & $\begin{array}{l}\text { Ocean and bush access were } \\
\text { not accessible to villagers, and } \\
\text { wild foods did not play a } \\
\text { large role in dietary intakes. }\end{array}$ \\
\hline $\begin{array}{c}\text { Food loss and waste, and } \\
\text { preservation }\end{array}$ & $\begin{array}{l}\text { A total of } 26.9 \% \text { (SD 16.5) of } \\
\text { food was self-reported lost or } \\
\text { wasted, with primary foods } \\
\text { being vegetables, starchy } \\
\text { staples, and nuts/seeds; } \\
\approx 30 \% \text { of villagers dried or } \\
\text { smoked food for preservation. }\end{array}$ & $\begin{array}{l}\text { A total of } 29.1 \% \text { (SD } 11.3 \text { ) of } \\
\text { food was self-reported lost or } \\
\text { wasted, with primary foods } \\
\text { being vegetables, fruits, and } \\
\text { starchy staples; } \approx 25 \% \text { of } \\
\text { villagers dried or smoked } \\
\text { food for preservation. }\end{array}$ & $\begin{array}{l}\text { A total of } 31.1 \% \text { (SD 11.1) of } \\
\text { food was self-reported lost or } \\
\text { wasted, with primary foods } \\
\text { being vegetables, fruits, and } \\
\text { starchy staples. Few in the } \\
\text { urban setting practiced food } \\
\text { preservation techniques. }\end{array}$ \\
\hline
\end{tabular}

\subsection{Excluded Data}

One participant's dietary data were removed due to underreporting (Goldberg cutoff point of $>1.96)$.

\subsection{Anthropometric and Physical Activity Measures}

Rural populations, on average, had significantly lower body fat percentage, BMI, and waist circumference when compared to urban populations (Table 2). Rural villagers exerted 853 more MET minutes per week of physical activity than the urban population, with the majority of rural participants achieving "high activity" levels. However, $90.1 \%$ of urban and $93.8 \%$ of inland rural participants achieved the physical activity recommendations of 600 weekly MET minutes set by the WHO. BMI was highly correlated with both body fat percentage $\left(p \leq 0.0001, r^{2}=0.73\right)$, waist circumference $\left(p \leq 0.0001, r^{2}=0.77\right)$, and calf circumference $\left(p \leq 0.0001, r^{2}=0.47\right)$.

Table 2. Mean anthropometric, health, and diet quality indicators across rural coastal, rural inland, and urban Solomon Island populations $(n=94)$.

\begin{tabular}{|c|c|c|c|c|}
\hline Indicator & Rural (Coastal) & Rural (Inland) & Urban & Overall (Average) \\
\hline \multicolumn{5}{|c|}{ Anthropometrics and health } \\
\hline Age & 37.1 & 39.8 & 37.0 & 37.9 \\
\hline Body fat percentage (\%) & 30.1 & 30.6 & $35.9 *$ & 32.4 \\
\hline BMI & 26.1 & 26.7 & $30.2 *$ & 27.7 \\
\hline Waist circumference $(\mathrm{cm}) *$ & - & 90.9 & $96.8 *$ & 93.9 \\
\hline Calf circumference $(\mathrm{cm}) *$ & - & 35.4 & $37.6 * *$ & 36.5 \\
\hline MET minutes (average/week)* & - & $4338^{*}$ & 3503.2 & 3920.6 \\
\hline$\%$ Low activity & - & $6 \%$ & $13 \%$ & $9.5 \%$ \\
\hline$\%$ Moderate activity & - & $41 \%$ & $54 \%$ & $47.5 \%$ \\
\hline$\%$ High activity & - & $53 \%$ & $33 \%$ & $43 \%$ \\
\hline \multicolumn{5}{|c|}{ Diet quality } \\
\hline Dietary species richness (DSR) & $7.1^{*}$ & 6.7 & 5.8 & 6.5 \\
\hline MDD-W (DDS) & $4.2 * *$ & 3.8 & 3.7 & 3.9 \\
\hline$\%$ DDS $\geq 5$ & $26.6 \% * *$ & $13.1 \%$ & $12.1 \%$ & $17.2 \%$ \\
\hline$\%>400 \mathrm{~g}$ NSFV & $79.2 \%$ & $77.4 \%$ & $42.2 \%$ ** & $66.2 \%$ \\
\hline Diet \% ultra-processed (NOVA 4) & 6.8 & 11.7 & $17.9 *$ & 12.13 \\
\hline Takeout (\#/week) * & - & 0.3 & $1.3 *$ & 0.8 \\
\hline
\end{tabular}

${ }^{*} p \leq 0.001,{ }^{* *} p \leq 0.01$. Waist circumference, calf circumference, MET minutes, and takeout data not available for rural coastal village. 


\subsection{Dietary Quality and Diversity}

Diets in rural villages (both coastal and inland) largely were predominately sourced from self-cultivated and wild foods, including root vegetables (taro, cassava, and kumara), bananas (cooking and eating), dark green leafy vegetables (kasume fern, slippery cabbage), and coconut products (cream). Both types of rural villages sourced significant protein from canned tuna, but differences existed in terms of access to wild food. Coastal villagers wild-collected protein from the ocean and the bush, whereas inland villagers sourced their protein from the nearby river (ora, grey fish, and wild pig) as well as from the bush.

Diet quality differed significantly among the three study populations (Table 2). Dietary species richness (DSR) was significantly higher in rural populations. The number of species consumed was correlated to the utilization of wild and cultivated foods in both urban and rural populations $(r=0.13, p=0.003)$. The DDS mean score for rural coastal populations was significantly higher than for the rural inland population. The average number of participants across three sites achieving $>5$ DDS was $17.2 \%$, indicating a high percentage of participants are unlikely to achieve nutrient adequacy. The majority $(>75 \%)$ of participants in rural areas achieved the WHO recommendation of $>400 \mathrm{~g}$ of non-starchy fruits and vegetables daily, compared to less than half $(42.2 \%)$ of the urban population who met this recommendation. Ultra-processed foods (NOVA 4) were consumed exponentially according to proximity to the urban center, and the most commonly consumed such foods were white breads, instant noodles, donuts, Milo drink mix, milk tea, and sausages.

\subsection{Energy and Nutrient Intakes}

Energy, macronutrient, and micronutrient intakes for the study populations are compared in Table 3. The prevalence of inadequate micronutrient intake of each population is indicated in Figure 2. The rural coastal village had the highest prevalence of participants who did not achieve the EAR for micronutrients of concern, followed by the rural inland and urban sites. More than half of the calcium intake for the rural populations came from dark green leafy vegetables, including slippery cabbage, wild fern, and leaves from root crops. Potassium was low for the urban population due to lower intakes of green leafy vegetables and roots, tubers, and bananas. The prevalence of inadequate vitamin $\mathrm{A}_{\mathrm{eq}}$ and thiamine intakes were lower in the rural inland and urban food systems in part due to the rice fortification policy mandate in November 2018, which was enacted after data collection in the rural coastal food system. However, both rural food systems sourced significant quantities of vitamin $A_{\mathrm{eq}}$ from cultivated, purchased, or wild collected dark green leafy vegetables.

Nutrients that were low in rural food systems but not in urban ones were vitamin $B_{12}$ and selenium. Urban food systems sourced the majority of their vitamin $B_{12}$ from canned tuna (taiyo), and selenium was sourced from canned tuna (taiyo) as well as from fortified white rice. Low consumption of animal-sourced foods, including fish, dairy, and meats, contributed to low vitamin $\mathrm{B}_{12}$ intake in the rural villages. All three study sites, on average, did not exceed sodium recommendations.

Macronutrients in all three food systems supplied higher than the recommended intakes of saturated fats and total sugars (Figure 3). Saturated fats were primarily sourced from coconut and coconut products. Sugars were primarily included in the diet in the form of sugar-sweetened beverages. Only the rural inland food system was able to meet fiber recommendations. On average, rural populations did not achieve protein recommendations, whereas the urban population did (Figure 3). Overall, mean energy consumption for each population was met; however, deficiencies in essential nutrients remain, including protein, vitamin $B_{12}$, and calcium. 
Table 3. ANOVA comparisons of usual macro- and micronutrient intakes among three unique populations $(n=94)$.

\begin{tabular}{|c|c|c|c|c|}
\hline Nutrient & Rural Coastal & Rural Inland & Urban & Overall Average \\
\hline \multicolumn{5}{|c|}{ Macronutrients } \\
\hline $\begin{array}{l}\text { Usual energy intake } \\
\qquad(\mathrm{kJ})\end{array}$ & 7648.3 & 8549.7 & $9067.7^{* *}$ & 8421.9 \\
\hline Calories (kcal) & 1828.0 & 2043.4 & $2167.2 * *$ & 2012.9 \\
\hline Total fat (g) & 62.1 & $79.7 * *$ & 63.7 & 68.5 \\
\hline Saturated fat $(g)$ & $52.5 *$ & 43.8 & 33.9 & 43.4 \\
\hline Carbohydrates (g) & $224.7 *$ & 308.2 & 328.6 & 287.2 \\
\hline Sugars $(g)$ & 61.7 & 57.9 & 60.7 & 60.1 \\
\hline Dietary Fiber (g) & 22.8 & $33.2 *$ & 20.6 & 25.5 \\
\hline Protein $(\mathrm{g})$ & 40.7 & 42.2 & $56.5 *$ & 46.5 \\
\hline \multicolumn{5}{|c|}{ Micronutrients } \\
\hline Vitamin A eq ( $\mu \mathrm{g})$ & 379.8 & $908.9^{*}$ & 599.7 & 629.5 \\
\hline Vitamin $B_{1}(\mathrm{mg})$ & 0.67 & $1.5 *$ & $2.2 *$ & 1.5 \\
\hline Vitamin $\mathrm{B}_{2}$ & 0.61 & 0.81 & 0.64 & 0.69 \\
\hline Vitamin C (mg) & 84.7 & 193.4 * & 111.7 & 129.9 \\
\hline Calcium [Ca] (mg) & 290.7 & $483.7 *$ & 320.9 & 365.1 \\
\hline Sodium [Na] (mg) & 1376.8 & 1506.2 & $1934.2 *$ & 1605.7 \\
\hline Potassium [K] (mg) & 3204.6 * & $4386.5 *$ & 2284.9 & 3292.0 \\
\hline Magnesium [Mg] (mg) & 416.8 & $504.8^{*}$ & 257.6 & 393.1 \\
\hline Iron $[\mathrm{Fe}](\mathrm{mg})$ & $11.4^{*}$ & 16.9 & 16.1 & 14.8 \\
\hline Zinc $[\mathrm{Zn}](\mathrm{mg})$ & $8.17^{*}$ & 14.6 & 16.7 & 13.2 \\
\hline
\end{tabular}

${ }^{*} p \leq 0.001,{ }^{* *} p \leq 0.01$.

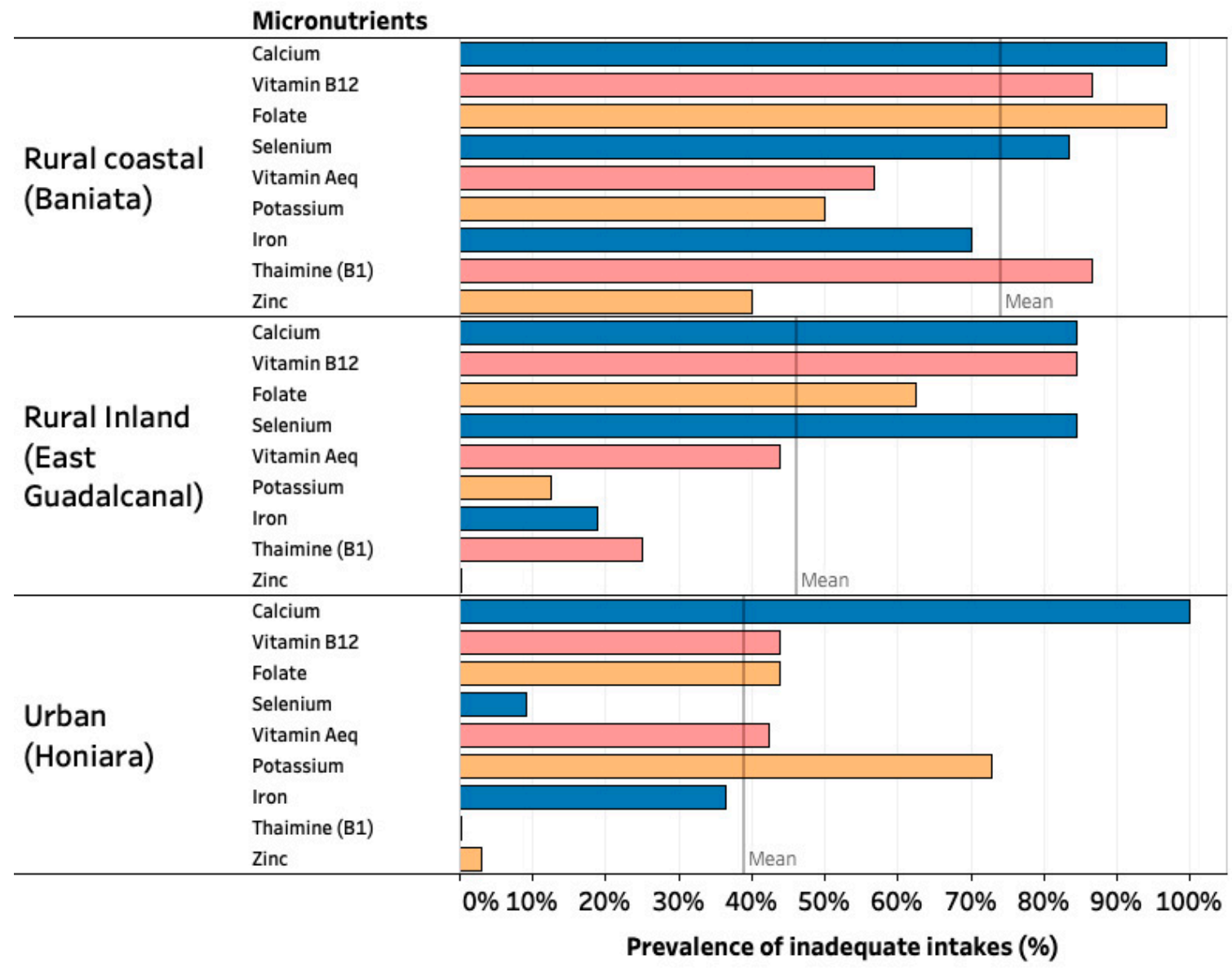

Figure 2. Prevalence of inadequate micronutrient intakes within three geographically distinct indigenous Solomon Islands food systems $(n=94)$. 


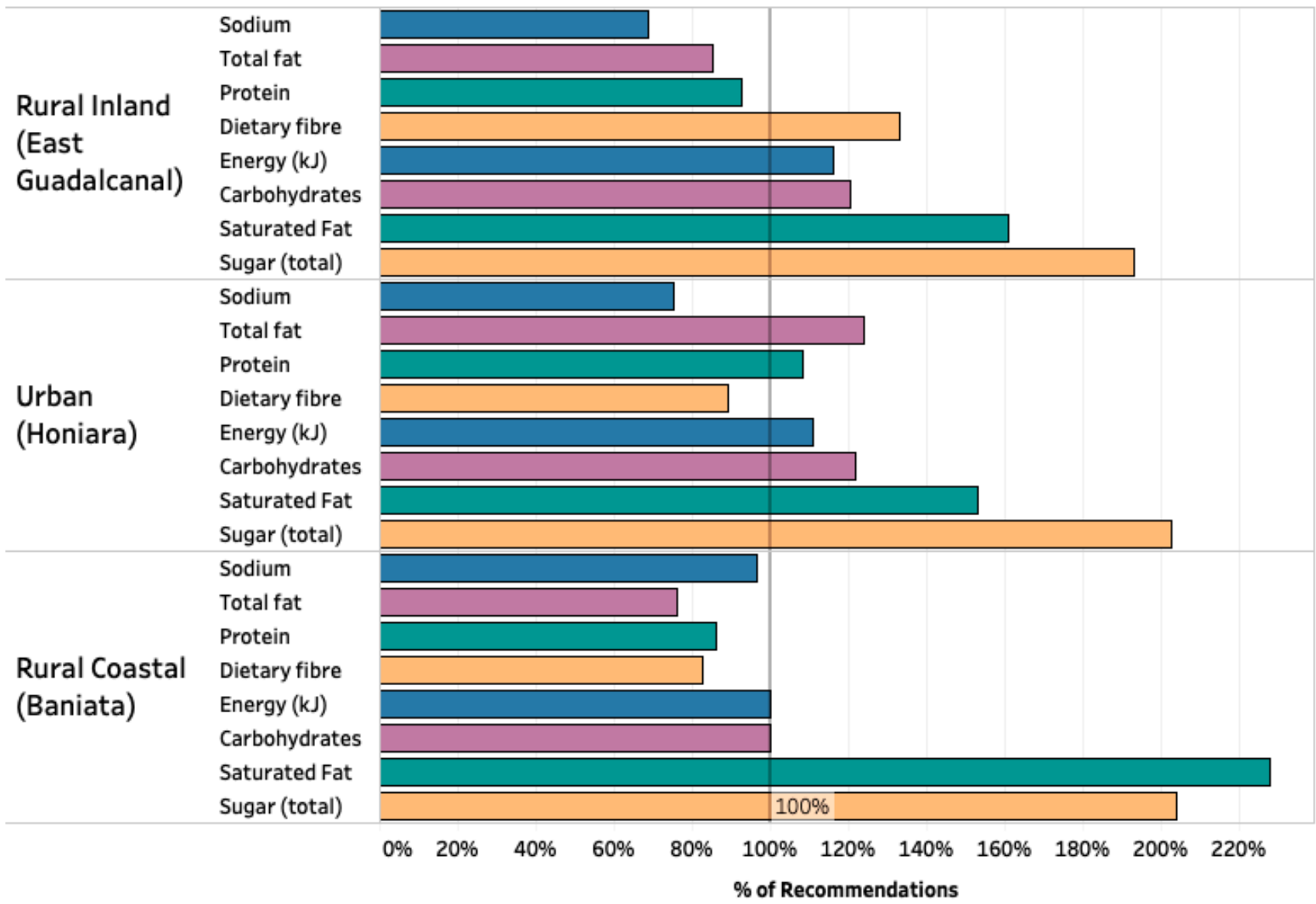

Figure 3. Macronutrient intakes compared with dietary recommendations in three geographically distinct food systems $(n=94)$. Energy requirements were compared to total energy expenditure (TEE) from basal metabolic rate (BMR) + physical activity level (PAL). Total fat recommendations $<30 \%$ total $\mathrm{kcal}$ and saturated fat recommendations $<10 \%$ of total $\mathrm{kcal}$ [33]. Sugar limits are sourced from WHO guidelines (2015) and salt limits from American Heart Association guidelines (2020).

Using a linear trend model, we found a significant decline in dietary energy (kJ) sourced from cultivated and wild collected foods among younger participants when compared with older participants in both rural and urban settings $(p \leq 0.001)$. There was a significant increase of store-bought foods in the urban population compared to the rural populations (Figure 4). Energy sources from wild foods were negligible in the urban populations when compared to the rural populations.

Table 4 compares the top five food sources of energy, iron, calcium, vitamin $A_{\text {eq }}$, and zinc in the rural inland and rural urban populations. Food energy from rural inland diets was sourced primarily from coconuts, root crops, and fortified white rice. In contrast, diets in the urban population were characterized by fortified white rice, fortified refined grain products, coconuts, cassava, and added sugars. Fortified white rice was the top contributor of zinc and iron for both rural inland and urban participants.

Through a linear regression analysis, we found that participants who had a higher knowledge of healthy diet patterns, consumed a wider diversity of species (DSR), and consumed more dark green leafy vegetables (by weight) were significantly more likely to have healthier body fat percentages $\left(p \leq 0.001, R^{2}=0.261\right.$ ). No significance was found between participants' body fat percentage and total energy consumption from NOVA 4 ultra-processed foods. 


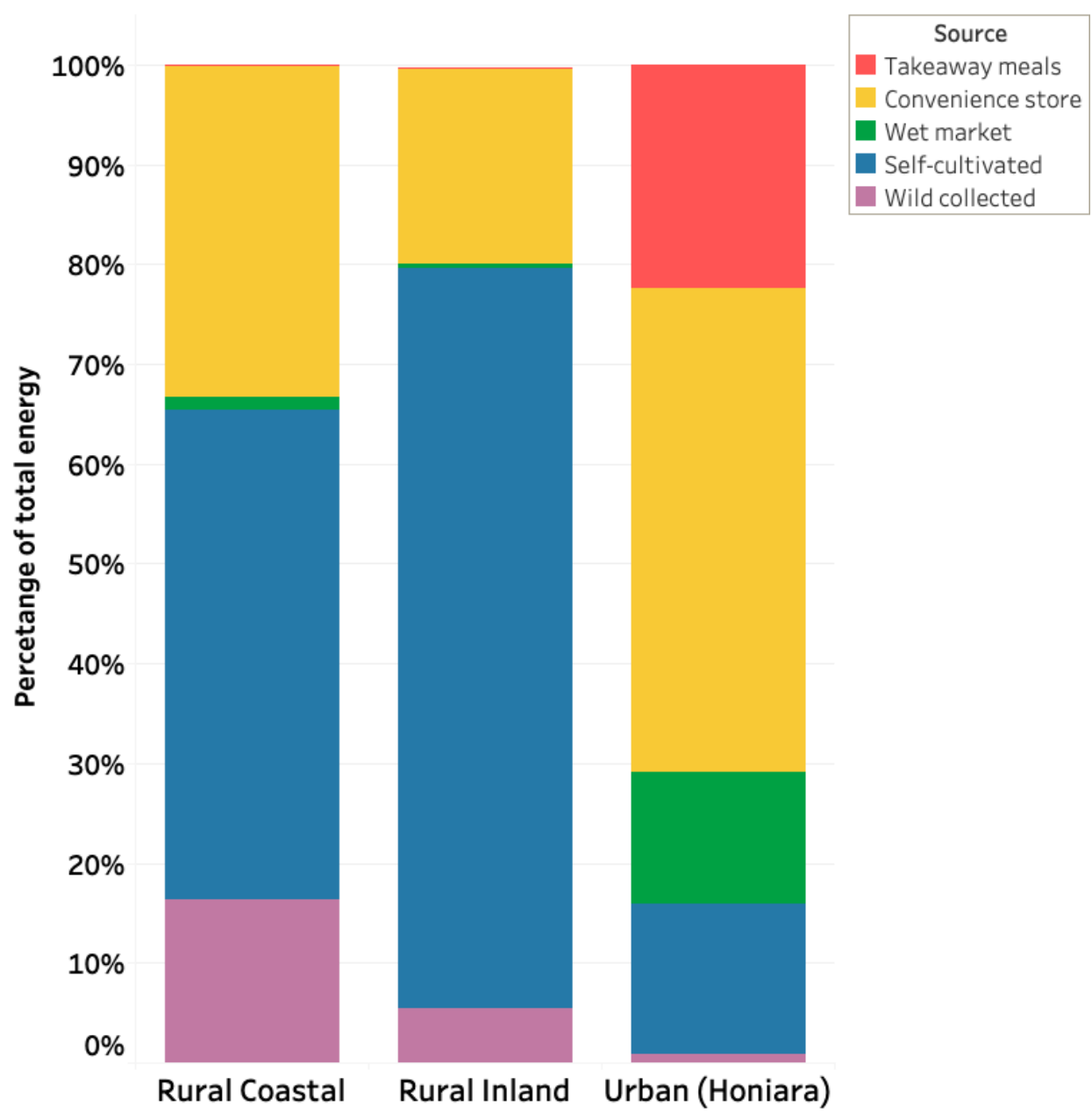

Figure 4. Energy food source patterns between three geographically unique indigenous Solomon Island populations $(n=94)$.

Table 4. Top five species contributing to energy, iron, calcium, vitamin $\mathrm{A}_{\mathrm{eq}}$, and zinc in diets.

\begin{tabular}{ccccc}
\hline$\#$ & Rural Inland & \% Total & Urban & $\%$ Total \\
\hline & & Energy (kJ) & & \\
1 & Coconuts & $24.07 \%$ & White rice & $28.13 \%$ \\
2 & Bananas & $21.26 \%$ & Refined wheat products & $18.36 \%$ \\
3 & White rice & $14.87 \%$ & Coconuts & $12.64 \%$ \\
4 & Taro (roots, leaves) & $7.03 \%$ & Cassava & $10.01 \%$ \\
5 & Sweet potatoes & $4.73 \%$ & Sugars (added) & $6.54 \%$ \\
& & & \\
1 & White rice & $21.11 \%$ & White rice & $44.37 \%$ \\
2 & Taro (roots, leaves) & $13.27 \%$ & Slippery cabbage (bele) & $9.17 \%$ \\
3 & Fern (wild) & $11.20 \%$ & Refined wheat products & $14.86 \%$ \\
4 & Coconut & $14.11 \%$ & Cassava (roots, leaves) & $6.58 \%$ \\
5 & Slippery cabbage (bele) & $7.41 \%$ & Tuna (canned, fresh) & $1.77 \%$ \\
& $\%$ of women below EAR & $18.8 \%$ & $\%$ of women below EAR & $36.4 \%$ \\
& & Calcium & Refined wheat products & $27.57 \%$ \\
1 & Taro & $38.68 \%$ & Slippery cabbage (bele) & $27.36 \%$ \\
2 & Slippery cabbage (bele) & $17.00 \%$ & Cassava (roots, leaves) & $9.00 \%$ \\
3 & Fern (wild) & $2.73 \%$ & Coconuts & $2.76 \%$ \\
4 & Pumpkin & $8.22 \%$ & Tuna (canned, fresh) & $1.10 \%$ \\
5 & Sweet potato & $4.41 \%$ & \% of women below EAR & $100.0 \%$ \\
\hline
\end{tabular}


Table 4. Cont.

\begin{tabular}{ccccc}
\hline$\#$ & Rural Inland & \% Total & Urban & \% Total \\
\hline & & Vitamin A (eq) & & \\
1 & Sweet potato & $71.21 \%$ & Slippery cabbage (bele) & $32.95 \%$ \\
2 & Slippery cabbage (bele) & $19.93 \%$ & Cassava (roots, leaves) & $26.20 \%$ \\
3 & Fern (wild) & $13.88 \%$ & Pumpkin (fruit, leaves) & $14.03 \%$ \\
4 & Taro (roots, leaves) & $11.01 \%$ & Oil (fortified) & $4.58 \%$ \\
5 & Pumpkin (fruit, leaves) & $7.33 \%$ & Taro (roots, leaves) & $2.62 \%$ \\
& \% of women below EAR & $43.8 \%$ & $\%$ of women below EAR & $42.4 \%$ \\
& & Zinc & White rice & $53.45 \%$ \\
2 & White rice & $29.94 \%$ & Cassava (roots, leaves) & $21.79 \%$ \\
3 & Taro (roots, leaves) & $16.85 \%$ & Cocined wheat products & $4.32 \%$ \\
4 & Cassava (roots, leaves) & $11.15 \%$ & Coconuts & $3.17 \%$ \\
5 & Fern (wild) & $9.33 \%$ & Slippery cabbage (bele) & $1.75 \%$ \\
& Coconuts & $8.85 \%$ & $\%$ of women below EAR & $3.0 \%$ \\
\hline
\end{tabular}

Results from the KAP survey (Figure 5) indicated that most women felt it was important to provide fruits $(93.6 \%)$ and vegetables $(95.7 \%)$ for their families $(n=94)$. Rural population attitudes towards the affordability of access to fruits and vegetables were slightly but significantly more favorable than among urban participants. Nearly half $(47.5 \%)$ of rural women felt meat was an important part of the diet, whereas only $21.7 \%$ of the urban population shared this view. There was a significant increase in urban women who felt it was difficult to get their children to eat fruits and vegetables when compared to the rural population $(27.7 \%$ and $50.1 \%$, respectively).

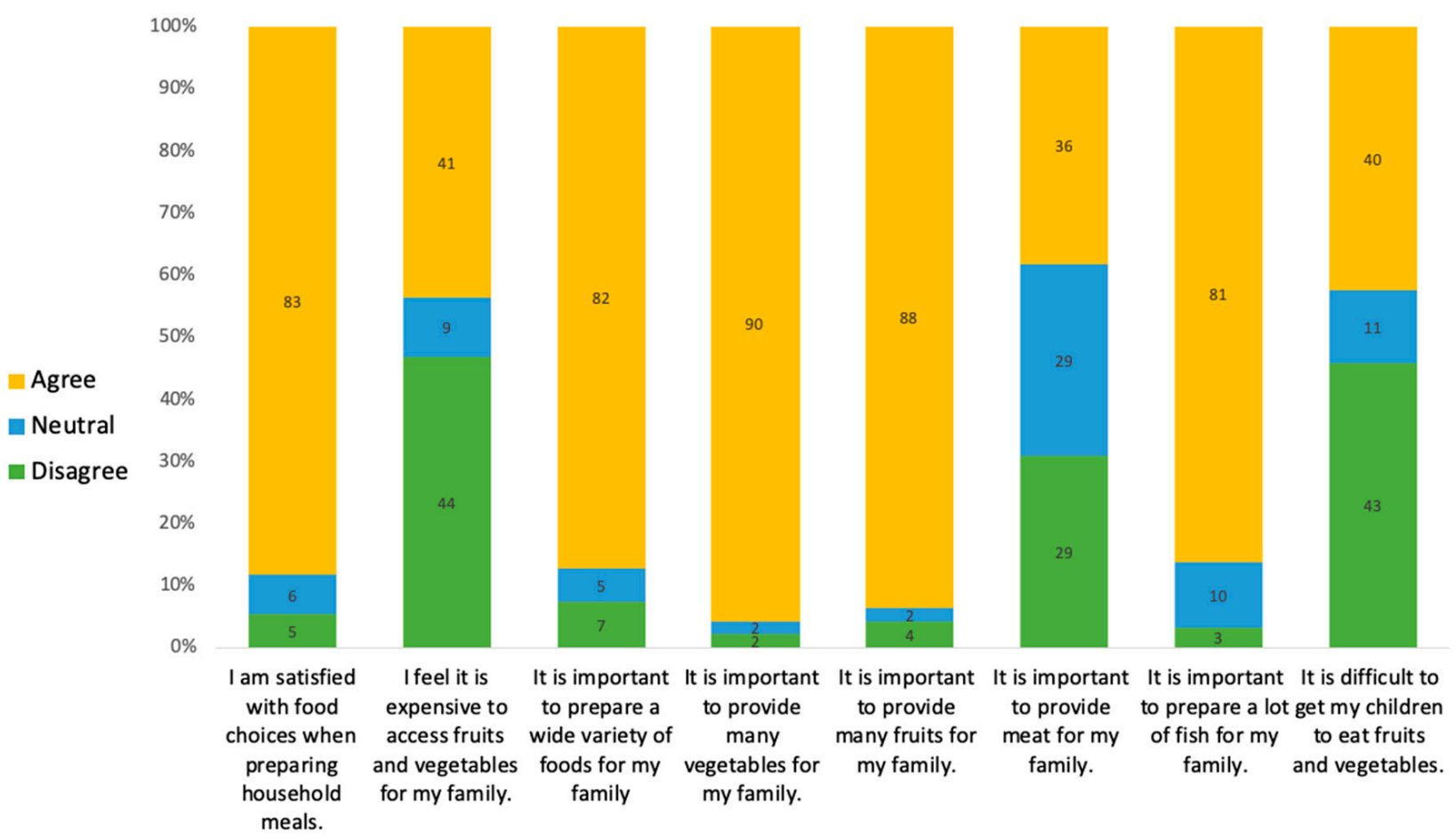

Figure 5. Knowledge, attitudes, and practice survey results among rural and urban women $(n=94)$.

\subsection{Qualitative Key Informant Interviews}

Village elders are the leaders of their respective communities in the Solomon Islands and are the primary host of the villager's traditional knowledge. Results for qualitative 
key informant interviews from each village elder's food system were summarized and categorized into three primary areas:

1. Traditional knowledge loss: Elders from all three study sites expressed their interest in sharing indigenous and traditional knowledge with the younger generations, but children were often unwilling to listen unless required. One elder summarized this concern by stating, "All traditional knowledge is passed, but kids do not want to do it."

2. Traditional food declines: Seasonal fluctuations of market produce prices within the urban population impact the ability to purchase certain locally grown foods. One elder added, "However, rice has filled the void of these fluctuations and cost barriers," and another added that "adults get tired of rice all the time, but kids only want rice. Now, the kids' preferences are influencing parents' preferences, too." Rural village elders expressed that local breeds and varieties are decreasing overall. Rural inland populations now cultivate their agri-foods $1 \mathrm{~h}$ away (walking) from their village to be closer to the road for easier market access, but this now limits the quantity of traditional foods that are carried back to the village. Additionally, rural inland villagers and urban villagers on the island of Guadalcanal are facing the recent threat of invasive giant African land snails (Achatina fulica), which decimate crops by the thousands. One elder stated, "We used to plant slippery cabbage near our house, but now the snails eat them all."

3. Climate change and weather patterns: Urban and rural elders expressed their concerns about climate change and associated weather pattern changes. Respondents said that dry seasons have decreased and that increases in rain throughout the year have caused many crops not to grow as well. One village elder shared the challenges to the local food system by stating, "We used to listen to the weather, but now we cannot."

\section{Discussion}

We found substantial differences in anthropometric measures, macronutrient and micronutrient intakes, and MET minutes between rural and urban Solomon Island populations. We also found significant differences in food sourcing patterns between rural and urban populations, with urban populations often replacing wild or self-cultivated agri-foods with purchased and ultra-processed foods. Overall, participants in rural areas sourced more energy from wild and cultivated foods; consumed a wider diversity of foods; had a higher probability of meeting WHO recommendations of $>400 \mathrm{~g}$ of NSFV daily; were more active physically; and had significantly lower body fat percentages, waist circumference, and BMI when compared to urban populations. Overall, an average of $17 \%$ of the study population achieved dietary diversity scores (MDD-W) $\geq 5$, slightly higher than recent diet diversity findings from populations living in the semi-urban areas of Malaita [13].

Since our data collection in the rural coastal village of Baniata in 2018, rice, wheat flour, and vegetable oil have been fortified with zinc, iron, vitamin $A_{\text {eq }}$, and thiamine (2019). Since a larger proportion of participants achieved intakes above the EAR for these micronutrients in both rural inland and urban populations, fortification may be a significant influencing factor of nutrient adequacy for these select nutrients. Fortified white rice was the main source of zinc for rural inland and urban populations. Salt is fortified with iodine, and most participants achieved the EAR. Food fortification may solve single micronutrient deficiencies but could ultimately reduce the sustainability of indigenous food system and give rise to diet-related noncommunicable diseases (NCDs), particularly since most fortified foods are imported and tend to be processed.

Urban populations consumed significantly more protein and ultra-processed foods (NOVA 4), were more likely to eat takeout foods, and had less diverse diets compared to rural populations. Less than half of urban participants met their recommended NSFV intakes. Whole, minimally processed foods contain a wide diversity of antioxidants, phytochemicals that protect against heart disease, T2DM, and obesity [34-36], of which 
urban populations are less likely to eat due to lack of accessibility. If ultra-processed foods (NOVA 4) continue to displace traditional foods, as evidenced by trends across the broader Pacific [6], NCD risks will likely continue to rise, even if levels of essential micronutrients are met through fortified foods. Additionally, modelling of staple crops predict that protein content and micronutrients of rice and wheat will decline significantly as atmospheric carbon dioxide rises [37]. Populations that rely heavily on single staple foods as their primary source of nutrition will experience proportional adverse impacts of these nutrient losses, aggravating existing cases of malnutrition and encouraging new ones [38].

Seafood is a critical and culturally important food for achieving food and nutrition security in the Solomon Islands. Urban participants sourced vitamin $B_{12}$ primarily from canned tuna (taiyo), as well as selenium from canned tuna and fortified white rice. Low consumption of animal-sourced foods, including fish, dairy, and meats, contribute to low vitamin $B_{12}$ and protein intake in rural populations. Low vitamin $B_{12}$ intake can result in irreversible neurological damage if $B_{12}$ is underconsumed for long periods [39]. Some options to ensure adequate vitamin $B_{12}$ intake within vulnerable populations include the promotion of more animal-sourced foods, supplementation, and fortification. Tuna catches are predicted to rise in PSIDS over the next 50 to 80 years due to changing ocean currents, potentially serving as a regionally abundant source of protein and other essential nutrients for current and future food systems [40]. In the short term, canned fish can help fill the gap between sustainable coastal fish production and recommended fish intakes [40].

Dietary diversity was found to be lower in the rural inland site than in the rural coastal site, which is likely related to the inland villagers' current struggle with the invasive giant African land snail (Achatina fulica). This destructive snail appeared in Guadalcanal rivers nearly three years ago, and has caused widespread damage to numerous crops of value, including kumara, slippery cabbage, and bananas. Villagers shared that their tolerance is low for this invasive species and that it is causing great stress. More data are needed examining the impacts from African snails in relation to diet quality, particularly for maternal and child health. While snails are not currently consumed, they are edible (when properly prepared), and provide essential trace minerals needed for optimal growth and development, including iron, magnesium, calcium, phosphorus, and potassium [41]. If culturally appropriate, education around the preparation and consumption of giant African snails may help to mitigate malnutrition in vulnerable populations such as children and pregnant women. An additional contribution to reduced dietary diversity within the rural inland site is that home gardens have recently moved further away from homes (a $1.5 \mathrm{~h}$ walk) and closer to the main road where transportation is available to reach produce markets. This increased distance from gardens to homes may impact household diet diversity as the food's weight and space are of concern when hiking back from the gardens.

Calcium is a nutrient of concern for all populations. Calcium-rich foods are primarily sourced from starchy staples and dark green vegetables, with the exception of the urban population, who source most calcium from refined grain products. Betel nuts (Areca catechu) are a commonly chewed stimulant drug, used regularly by $45 \%$ of participants in urban and rural sites. Consumed alongside the nut is dried, crushed coral (calcium carbonate; $\left.\mathrm{CaCO}_{3}\right)$, which may provide $>100 \%$ of the user's EAR for calcium $(3 \mathrm{~g}=1000 \mathrm{mg}$, or $>100 \%$ EAR). However, betel nuts are a highly addictive and accessible cancer-causing drug [42].

Ultra-processed foods (NOVA 4) have the worst nutrient profiles yet are becoming the most prevalent foods within global food systems, including in the neighboring countries of Australia and New Zealand $[43,44]$. NOVA 4 were consumed in all three study sites, with the highest consumption within the urban population. Interestingly, the consumption of ultra-processed foods had no correlation with body fat percentage or BMI. However, numerous global studies have found significant inverse associations between consumption of NOVA 4 foods and fiber, potassium, and micronutrients [45]. The most common ultraprocessed foods were doughnuts, bread, instant noodles, Milo drink mix, and sausages. Takeaway meals consisting of fried meats or fish, sausages, and rice were more common in 
the urban populations. Fewer ultra-processed foods have made their way to rural areas, likely due to the journey required to access the villages.

Our findings suggest that higher body fat percentages were highly correlated with higher BMIs and waist circumferences, and therefore body fat percentage was used as a primary health indicator due to its relation to NCDs and chronic disease risk [46-48]. We found that lower body fat percentages were significantly correlated with a greater intake of unique numbers of species, higher knowledge of healthy diets, and increased intakes of dark leafy green vegetables. These results align with observations from Tsuchiya et al. (2017), where lower frequencies of green leafy vegetable consumption and dietary diversity were associated with increased rates of obesity in the urban setting of Honiara [49].

Food insecurity was classified as moderate in the rural coastal community and classified as low in the rural inland and urban communities. Food security is often provided through "insurance crops", such as swamp taro; kasume (wild fern); and, more recently, imported white rice. Nutrition security, however, is nonetheless a cause for concern, as adequate supplies of essential nutrients are not available year-round per current food system availability [50].

Recent findings from Solomon Island populations indicate that overall nutrition knowledge is weak, which can impede informed choices regarding food consumption [13]. Additionally, urban women in our study perceived getting children to eat fruits and vegetables to be twice as challenging as women in the rural settings. This difference could be related to changes in urban food environments, including advertisements, lack of cultivation opportunities, or perceptions that traditional foods are old-fashioned. Nearly half of rural women felt meat was an important part of the diet, whereas only $21.7 \%$ of urban participants shared this view. This could be related to the sourcing of meat, in that in rural settings meat is typically sourced from the bush, whereas in urban settings meat is typically consumed via less healthy sources such as processed sausages or fried chicken.

Both urban and rural village elders expressed their concerns regarding the loss of traditional knowledge, as well as concerns for an increasing reliance on less healthful, imported foods. While imported foods can fit into a healthful diet, it is important to recognize the potential sustainability trade-offs associated with displacing traditional foods rich in nutrients with energy-dense imported and ultra-proceeded foods. Other Melanesian PSIDS, such as Fiji, have much higher rates of childhood and adult obesity compared to the Solomon Islands, likely associated with a lengthier exposure to energy-dense and nutrient-poor foods [51].

\subsection{Implications and Further Research}

Indigenous knowledge can help build local food system resilience, strengthen food and nutrition security, and help to inform the global debate on improving the sustainability of global food systems [52]. Studies have identified that agroecological approaches informed by participatory research and indigenous knowledge can help empower communities and increase food sovereignty [53]. Neglected and underutilized agri-food species also have the potential to generate income for farmers, meet demand in local markets, and contribute to meeting UN sustainability goals [1].

A recent technical report identified community food production initiatives in PSIDS as part of the solution for addressing food and nutrition insecurity by increasing dietary diversity and incomes while reducing household food expenditure [54]. Strategies aiming to improve the nutrition and health outcomes of indigenous food systems should begin with the inclusion of traditional knowledge, values, and priorities. Additionally, convenience, affordability, and income-generating opportunities are important considerations when aiming to improve food systems' contributions to human and planetary health. Future research should examine how the multiple dimensions of sustainable diets, including nutritional, environmental, economic, and sociocultural, can be achieved. Utilizing and promoting the food-based dietary guidelines for the Solomon Islands can help guide 
policies and educational efforts towards culturally significant, nutritious, and balanced diets.

Lastly, a deeper examination of ingredients used within ultra-processed foods is warranted, particularly those containing trans fatty acids under the ingredient name "partially hydrogenated oil". Trans fatty acids have historically been poorly displayed on nutrition facts labels in Solomon Islands, findings that are confirmed by a large-scale study examining completeness of nutrition information facts with 6000+ food and drinks in Fiji [55]. Trans fatty acids, even in small quantities, are extremely deleterious to cardiovascular health and overall NCD risk [56].

\subsection{Limitations}

The $24 \mathrm{~h}$ multiple pass dietary recall methodology has not been adapted for a Solomon Islands population, and therefore population-specific adjustments are not known. However, we countered this limitation by using the Goldberg cutoff methodology to reduce the likelihood of under- and over-reporting. Another limitation is that BMI cut points have not been established for Melanesian populations, and therefore we used additional metrics such as body fat percentage and waist circumference. There was a one-year span between the first round of data collection (2018) and the second (2019). Researchers controlled for this by conducting the study during the same time of year, but also acknowledge this as a limitation. Sample populations were selected to represent three geographically distinct environments in which the majority of Solomon Islanders live. However, Solomon Islands is an archipelago of $900+$ islands with over 75 distinct languages, and therefore each community has unique challenges and opportunities when aiming to obtain food and nutrition security. Additional food systems research is required to further understand dietary diversity, quality, and transitions in more remote island locations. Food composition data are severely lacking for a wide diversity of available varieties of foods across the Pacific. Updating the Pacific food composition tables can help provide food-based and culturally significant solutions to mitigating malnutrition.

\section{Conclusions}

Clear anthropometric, diet-quality, and sourcing differences were found between rural and urban participants. We found urban populations to be at a significantly increased risk for obesity and NCDs. Estimated requirements of zinc, iron, folate, and vitamin $\mathrm{A}_{\mathrm{eq}}$ were met by the majority of participants after fortification mandates for rice, flour, and oil were enacted in November 2018. These fortifications should improve malnutrition outcomes for vulnerable populations. However, fortified foods may artificially inflate individuals confidence in the quality of their diets, since our findings indicate that traditional foods are being displaced by imported and ultra-processed foods. As urbanization increases, declines in knowledge of traditional agri-food are accelerated through shifts towards industrially processed foods and changes in the taste preferences of younger generations.

Villagers expressed strong interest in understanding how they can improve their diets to achieve better nutrition outcomes within their communities. Elders expressed grave forecasts about traditional knowledge losses, changing dietary patterns, and climate change. Certain processed foods, particularly those which are locally produced, can play a critical role in achieving food and nutrition security as well as food sovereignty-a critically important concept given the recent food system disruptions caused by the COVID19 pandemic. Unless action is taken to preserve and integrate traditional knowledge, associated food and nutrition security benefits will likely continue to rapidly erode. There are clear opportunities to leverage traditional knowledge and improve cultivation and consumption of neglected and underutilized species that can help build more sustainable and resilient food systems while ensuring indigenous knowledge and cultural preferences are preserved. 
Author Contributions: Conceptualization, C.V., J.C., C.W., and B.B.; methodology, C.V.; investigation, C.V., J.M., and J.E.R.; writing-Original draft preparation, C.V.; writing-Review and editing, J.C., C.W., J.M., and J.E.R.; visualization, C.V. All authors have read and agreed to the published version of the manuscript.

Funding: This research received funding from a grant from Massey University's Research Fund awarded to J.C. (MURF).

Data Availability Statement: The data presented in this study are available freely upon request from the corresponding author.

Acknowledgments: The authors would like to acknowledge and thank the Solomon Island communities for their generosity in sharing their time and knowledge with us. We would also like to thank Massey University of New Zealand and Solomon Islands National University for their participation in this research. A special thanks to the nutritionist enumerators who helped to collect and enter the data of all three populations.

Conflicts of Interest: The authors declare no conflict of interest.

\section{References}

1. Swinburn, B.A.; Kraak, V.I.; Allender, S.; Atkins, V.J.; Baker, P.I.; Bogard, J.R.; Brinsden, H.; Calvillo, A.; De Schutter, O.; Devarajan, R. The global syndemic of obesity, undernutrition, and climate change: The Lancet Commission report. Lancet 2019, 393, 791-846. [CrossRef]

2. Turner, N.J.; Plotkin, M.; Kuhnlein, H.V. Global environmental challenges to the integrity of Indigenous Peoples' food systems. In Indigenous Peoples' Food Systems and Well-Being: Interventions and Policies for Healthy Communities; FAO: Rome, Italy, 2013; pp. 23-38.

3. Hunter, D.; Fanzo, J. Introduction: Agricultural biodiversity, diverse diets and improving nutrition. In Diversifying Food and Diets; Routledge: Abingdon-on-Thames, UK, 2013; pp. 33-46.

4. Burlingame, B.; Vogliano, C.; Eme, P.E. Leveraging agricultural biodiversity for sustainable diets, highlighting Pacific Small Island Developing States. Adv. Food Secur. Sustain. 2019, 133-173. [CrossRef]

5. Vogliano, C.; Wham, C.; Coad, J.; Burlingame, B. Can Leveraging Agrobiodiverse Food Systems Help Reverse the Rise of Malnutrition in Pacific Small Island Developing States (PSIDS)? Proceedings 2019, 37, 18. [CrossRef]

6. Sievert, K.; Lawrence, M.; Naika, A.; Baker, P. Processed Foods and Nutrition Transition in the Pacific: Regional Trends, Patterns and Food System Drivers. Nutrients 2019, 11, 1328. [CrossRef]

7. Hamilton, R.J.; Almany, G.R.; Brown, C.J.; Pita, J.; Peterson, N.A.; Choat, J.H. Logging degrades nursery habitat for an iconic coral reef fish. Biol. Conserv. 2017, 210, 273-280. [CrossRef]

8. Gibson, J. Forest loss and economic inequality in the Solomon Islands: Using small-area estimation to link environmental change to welfare outcomes. Ecol. Econ. 2018, 148, 66-76. [CrossRef]

9. HLPE. Food Security and Nutrition: Building a Global Narrative towards 2030. A Report by the High. Level Panel of Experts on Food Security and Nutrition of the Committee on World Food Security; FAO: Rome, Italy, 2020.

10. FAO. The future of food and agriculture-Trends and challenges. In Annual Report; FAO: Rome, Italy, 2017.

11. Andersen, A.; Thilsted, S.; Schwarz, A. Food and Nutrition Security in Solomon Islands. CGIAR Research Program on Aquatic Agricultural Systems; Working Paper: AAS-2013-06; WorldFish: Penang, Malaysia, 2013.

12. Horsey, B.; Swanepoel, L.; Underhill, S.; Aliakbari, J.; Burkhart, S. Dietary Diversity of an Adult Solomon Islands Population. Nutrients 2019, 11, 1622. [CrossRef]

13. Albert, J.; Bogard, J.; Siota, F.; McCarter, J.; Diatalau, S.; Maelaua, J.; Brewer, T.; Andrew, N. Malnutrition in rural Solomon Islands: An analysis of the problem and its drivers. Matern. Child Nutr. 2020, 16, e12921. [CrossRef]

14. Butte, N.F.; King, J.C. Energy requirements during pregnancy and lactation. Public Health Nutr. 2005, 8, 1010-1027. [CrossRef]

15. Centers For Disease Control and Prevention. National Health and Nutrition Examination Survey (Nhanes): Anthropometry Procedures Manual; Centers for Disease Control and Prevention: Atlanta, GA, USA, 2007.

16. Gibson, R.S.; Charrondiere, U.R.; Bell, W. Measurement errors in dietary assessment using self-reported 24-h recalls in low-income countries and strategies for their prevention. Adv. Nutr. 2017, 8, 980-991. [CrossRef]

17. Charrondiere, U.; Haytowitz, D.; Stadlmayr, B. FAO/INFOODS density database, version 2.0. In Proceedings of Food and Agriculture Organization of the United Nations Technical Workshop Report; FAO: Rome, Italy, 2012.

18. Dignan, C.; Burlingame, B.; Kumar, S.; Aalbersberg, W. The Pacific Islands Food Composition Tables; FAO: Rome, Italy, 2004.

19. Harttig, U.; Haubrock, J.; Knüppel, S.; Boeing, H. The MSM program: Web-based statistics package for estimating usual dietary intake using the Multiple Source Method. Eur. J. Clin. Nutr. 2011, 65, S87-S91. [CrossRef] [PubMed]

20. Monteiro, C.A.; Cannon, G.; Levy, R.B.; Moubarac, J.-C.; Louzada, M.L.; Rauber, F.; Khandpur, N.; Cediel, G.; Neri, D.; MartinezSteele, E. Ultra-processed foods: What they are and how to identify them. Public Health Nutr. 2019, 22, 936-941. [CrossRef] [PubMed]

21. FAO, F. Minimum Dietary Diversity for Women: A Guide for Measurement; FAO: Rome, Italy, 2016; Volume 82. 
22. Lachat, C.; Raneri, J.E.; Smith, K.W.; Kolsteren, P.; Van Damme, P.; Verzelen, K.; Penafiel, D.; Vanhove, W.; Kennedy, G.; Hunter, D. Dietary species richness as a measure of food biodiversity and nutritional quality of diets. Proc. Natl. Acad. Sci. USA 2018, 115, 127-132. [CrossRef] [PubMed]

23. Cafiero, C.; Viviani, S.; Nord, M. Food security measurement in a global context: The food insecurity experience scale. Measurement 2018, 116, 146-152. [CrossRef]

24. Smith, M.D.; Rabbitt, M.P.; Coleman-Jensen, A. Who are the world's food insecure? New evidence from the Food and Agriculture Organization's food insecurity experience scale. World Dev. 2017, 93, 402-412. [CrossRef]

25. IPAQ. Guidelines for Data Processing and Analysis of the International Physical Activity Questionnaire (IPAQ)—Short and Long Forms. Available online: http:/ / www.ipaq.ki.se/scoring.htm (accessed on 1 July 2018).

26. Marías, Y.; Glasauer, P. Guidelines for Assessing Nutrition-Related Knowledge, Attitudes and Practices; Food and Agriculture Organization of the United Nations (FAO): Rome, Italy, 2014.

27. World Health Organization. Vitamin and Mineral Requirements in Human Nutrition; World Health Organization: Geneva, Switzerland, 2004.

28. Institute of Medicine (US) Subcommittee on Interpretation and Uses of Dietary Reference Intakes; Institute of Medicine (US) Standing Committee on the Scientific Evaluation of Dietary Reference Intakes. Dri Dietary Reference Intakes: Applications in Dietary Assessment; National Academies Press (US): Washington, DC, USA, 2000.

29. Council, N.R. The probability approach. In Nutrient Adequacy: Assessment Using Food Consumption Surveys; National Academies Press (US): Washington, DC, USA, 1986.

30. World Health Organization. Fruit and Vegetables for Health: Report of the Joint FAO/WHO; World Health Organization: Kobe, Japan, 2005.

31. Roza, A.M.; Shizgal, H.M. The Harris Benedict equation reevaluated: Resting energy requirements and the body cell mass. Am. J. Clin. Nutr. 1984, 40, 168-182. [CrossRef]

32. Black, A. The sensitivity and specificity of the Goldberg cut-off for EI: BMR for identifying diet reports of poor validity. Eur. J. Clin. Nutr. 2000, 54, 395-404. [CrossRef]

33. Hooper, L.; Martin, N.; Abdelhamid, A.; Smith, G.D. Reduction in saturated fat intake for cardiovascular disease. Cochrane Database Syst. Rev. 2015, 10, CD011737. [CrossRef]

34. Da Silveira Vasconcelos, M.; de Oliveira, L.M.N.; Mota, E.F.; de Siqueira Oliveira, L.; Gomes-Rochette, N.F.; Nunes-Pinheiro, D.C.S.; Nabavi, S.M.; de Melo, D.F. Consumption of rich/enrich phytonutrients food and their relationship with health status of population. In Phytonutrients in Food; Elsevier: Amsterdam, The Netherland, 2020; pp. 67-101.

35. Jha, P.; Kumari, S.; Jobby, R.; Desai, N.; Ali, A. Dietary phytonutrients in prevention of diabetes related complications. Curr. Diabetes Rev. 2020, 16, 657-673. [CrossRef]

36. Orgeron, R., II; Pope, J.; Green, V.; Erickson, D. Phytonutrient intake and body composition: Considering colors. Funct. Foods Health Dis. 2019, 9, 108-122. [CrossRef]

37. Zhu, C.; Kobayashi, K.; Loladze, I.; Zhu, J.; Jiang, Q.; Xu, X.; Liu, G.; Seneweera, S.; Ebi, K.L.; Drewnowski, A. Carbon dioxide $\left(\mathrm{CO}_{2}\right)$ levels this century will alter the protein, micronutrients, and vitamin content of rice grains with potential health consequences for the poorest rice-dependent countries. Sci. Adv. 2018, 4, eaaq1012. [CrossRef] [PubMed]

38. Smith, M.R.; Myers, S.S. Impact of anthropogenic CO 2 emissions on global human nutrition. Nat. Clim. Chang. 2018, 8, 834-839. [CrossRef]

39. Green, R.; Allen, L.H.; Bjørke-Monsen, A.-L.; Brito, A.; Guéant, J.-L.; Miller, J.W.; Molloy, A.M.; Nexo, E.; Stabler, S.; Toh, B.-H. Vitamin B 12 deficiency. Nat. Rev. Dis. Prim. 2017, 3, 1-20.

40. Bell, J.D.; Sharp, M.K.; Havice, E.; Batty, M.; Charlton, K.E.; Russell, J.; Adams, W.; Azmi, K.; Romeo, A.; Wabnitz, C.C.C.; et al. Realising the food security benefits of canned fish for Pacific Island countries. Mar. Policy 2019, 100, 183-191. [CrossRef]

41. Fagbuaro, O.; Oso, J.; Edward, J.; Ogunleye, R. Nutritional status of four species of giant land snails in Nigeria. J. Zhejiang Univ. Sci. B 2006, 7, 686-689. [CrossRef]

42. Moore, M.A.; Baumann, F.; Foliaki, S.; Goodman, M.T.; Haddock, R.; Maraka, R.; Koroivueta, J.; Roder, D.; Vinit, T.; Whippy, H.J. Cancer epidemiology in the Pacific Islands-past, present and future. Asian Pac. J. Cancer Prev. APJCP 2010, 11, 99-106.

43. Luiten, C.M.; Steenhuis, I.H.; Eyles, H.; Mhurchu, C.N.; Waterlander, W.E. Ultra-processed foods have the worst nutrient profile, yet they are the most available packaged products in a sample of New Zealand supermarkets. Public Health Nutr. 2016, 19, 530-538. [CrossRef]

44. Machado, P.P.; Steele, E.M.; da Costa Louzada, M.L.; Levy, R.B.; Rangan, A.; Woods, J.; Gill, T.; Scrinis, G.; Monteiro, C.A. Ultra-processed food consumption drives excessive free sugar intake among all age groups in Australia. Eur. J. Nutr. 2020, 59, 2783-2792. [CrossRef]

45. Monteiro, C.A.; Cannon, G.; Lawrence, M.; Louzada, M.D.C.; Machado, P.P. Ultra-Processed Foods, Diet Quality, and Health Using the NOVA Classification System; FAO: Rome, Italy, 2019.

46. Hjartåker, A.; Langseth, H.; Weiderpass, E. Obesity and diabetes epidemics. In Innovative Endocrinology of Cancer; Springer: Berlin/Heidelberg, Germany, 2008; pp. 72-93.

47. McGee, D.L.; Collaboration, D.P. Body mass index and mortality: A meta-analysis based on person-level data from twenty-six observational studies. Ann. Epidemiol. 2005, 15, 87-97. [CrossRef] 
48. Oreopoulos, A.; Padwal, R.; Kalantar-Zadeh, K.; Fonarow, G.C.; Norris, C.M.; McAlister, F.A. Body mass index and mortality in heart failure: A meta-analysis. Am. Heart J. 2008, 156, 13-22. [CrossRef]

49. Tsuchiya, C.; Tagini, S.; Cafa, D.; Nakazawa, M. Socio-environmental and behavioral risk factors associated with obesity in the capital (Honiara), the Solomon Islands; case-control study. Obes. Med. 2017, 7, 34-42. [CrossRef]

50. Gibson, R.S.; Cavalli-Sforza, T. Using reference nutrient density goals with Food Balance Sheet data to identify likely micronutrient deficits for fortification planning in countries in the Western Pacific Region. Food Nutr. Bull. 2012, 33, S214-S220. [PubMed]

51. Micha, R.; Mannar, V.; Afshin, A.; Allemandi, L.; Baker, P.; Battersby, J.; Bhutta, Z.; Chen, K.; Corvalan, C.; Di Cesare, M. 2020 Global Nutrition Report: Action on Equity to End Malnutrition; Development Intiatives: Bristol, UK, 2020.

52. Hunter, D.; Özkan, I.; de Oliveira Beltrame, D.M.; Samarasinghe, W.L.G.; Wasike, V.W.; Charrondière, U.R.; Borelli, T.; Sokolow, J. Enabled or Disabled: Is the environment right for Using Biodiversity to improve Nutrition? Front. Nutr. 2016, 3, 14. [CrossRef] [PubMed]

53. Putnam, H.; Godek, W.; Kissmann, S.; Pierre, J.L.; Dzul, S.H.A.; de Dios, H.C.; Gliessman, S.R. Coupling agroecology and PAR to identify appropriate food security and sovereignty strategies in indigenous communities. Agroecol. Sustain. Food Syst. 2014, 38, 165-198. [CrossRef]

54. Iese, V.; Wairiu, M.; Fesaitu, J.; Teva, C.; Navunicagi, O.; Unwin, N.; Haynes, E.; Guell, C.; Francis, J. Building the Evidence Base on Community Food Production Initiatives in Pacific Island Countries Agriculture and Nutrition Series 34 CTA Technical Brief; CTA: Wageningen, The Netherlands, 2020. [CrossRef]

55. Snowdon, W.; Raj, A.; Reeve, E.; Guerrero, R.L.T.; Fesaitu, J.; Cateine, K.; Guignet, C. Processed foods available in the Pacific Islands. Glob. Health 2013, 9. [CrossRef] [PubMed]

56. Mozaffarian, D.; Katan, M.B.; Ascherio, A.; Stampfer, M.J.; Willett, W.C. Trans fatty acids and cardiovascular disease. N. Engl. J. Med. 2006, 354, 1601-1613. [CrossRef] 